symmetric and Hermitian matrices. This book, while familiar to the American public, was not available to me at the time, and I did not realize that the problem proposed had been completely settled previous to the occurrence of the war.

February 9, 1920.

\title{
DICKSON'S HISTORY OF THE THEORY OF NUMBERS.
}

ON page 130 of my review of Dickson's History I speak of two pages of titles at the end of Chapter XII as "not reported on." This is an error. With the exception of certain ones marked with an asterisk which give papers not obtainable by the author the content of the papers is sufficiently indicated, the papers not being of importance to warrant more detailed report.

The phrase "list of references," on the top of page 132, is perhaps misleading. Of course the book is in no sense to be compared with the useless lists of titles of papers which the compiler may or may not have glanced at. My intention in the paragraph was to bring out the distinction which modern historians seem to make between a list of events and the relations and connections between events.

D. N. LEHMER.

\section{NOTES.}

THE December number (volume 21, number 2) of the Annals of Mathematics contains the following papers: "A property of cyclotomic integers and its relation to Fermat's last theorem," by H. S. VANDIVER; "Surfaces of rotation in a space of four dimensions," by C. L. E. Moore; "The circle nearest to $n$ given points, and the point nearest to $n$ given circles," by J. L. CoOLIDGE; "Singular solutions of differential equations of the second order," by E. M. Coon and R. L. GoRDon; "Note on a class of integral equations of the second kind," by C. E. Love; "Concerning sense on closed curves in 
non-metrical plane analysis situs," by J. R. KurNe; “On the theory of summability," by GLENN JAMES; "On the consistency and equivalence of certain generalized definitions of the limit of a function of a continuous variable," by L. L. Sillverman.

THE Mathematical association of Japan for secondary education issued the first number of volume 1 of its Journal under date of April, 1919. It is published by M. KABA, of Tokyo, as chief editor, assisted by M. Kuroda, M. Watanabe, S. Nagao and H. Furukawa. Professor T. Hayashi is president of the Association.

IT is announced that a new quarterly devoted to the mathematics of finance, the Giornale di Matematica Finanziaria, will be published under the auspices of the higher institutes of commerce and the chambers of commerce of Turin and Genoa. The business offices are at 73, Corso Vittorio Emmanuele, Turin.

The Paris Academy of sciences has awarded its Bordin prize for 1919 to Professor S. LEFschetz, of the University of Kansas, for his memoir "On certain invariant numbers of algebraic varieties, with application to abelian varieties." The Academy announces the following subject for its Grand prize, to be awarded in 1922: The determination of extensive classes of surfaces by given properties of their geodesics considered in ordinary space.

Professor C. Servats, of the University of Ghent, has been elected an active member, and Professor T. DE Donder, of the University of Brussels, a corresponding member of the Belgian academy of sciences.

Professons J. Plemelu, of the University of Czernovitch, and R. SUPPANTSCHITSCH, of the technical school of Vienna, have been appointed professors of mathematics at the reorganized University of Lioubliana (Laibach), Jugoslavia.

Mr. J. H. JeAns, of Cambridge, formerly professor of mathematics at Princeton University, has been nominated as secretary of the Royal society of London. Professor G. N. 
Watson, of the University of Birmingham, has been elected a fellow of the society.

Sir J. J. Thomson, master of Trinity College, Cambridge, who recently resigned the Cavendish professorship of experimental physics, has been elected to the newly established professorship of physics.

Capt. L. L. Burchnall, scholar of Christ Church, Oxford, has been appointed lecturer in mathematics at the University of Durham.

Dr. R. J. T. BeLL, of the University of Glasgow, has been appointed to the chair of pure and applied mathematics in the University of Otago, New Zealand.

Professors N. B. Maclean and N. R. Wilson have returned to the University of Manitoba, from active service in France.

Professor E. W. Brown delivered a lecture on the history of mathematics before the Gamma Alpha fraternity of Yale University on February 26. This is the first of a series on the history of the several sciences. The Astronomical Society of the Pacific has awarded its Bruce Medal for 1920 to Professor Brown.

At Yale University, assistant professor W. R. LoNGLeY has been promoted to a professorship and Mr. J. K. WHITTEMORE to an assistant professorship of mathematics.

Professor P. P. Boyd, of the University of Kentucky, has been elected president of the Kentucky academy of sciences.

Boston University has concluded an arrangement for the exchange of professorships in mathematics for the college year 1920-1921 with Tsing Hua College, Peking, China. Professor R. E. BRUCE, chairman of the department in Boston University, will exchange with Professor A. H. HeInz, of Tsing Hua.

Assistant professor K. P. Williams, of Indiana University, has returned from military service and been promoted to an associate professorship of mathematics. 
Dr. C. C. Camp, of the University of Illinois, has been appointed assistant professor of mathematics at Iowa State College.

Assistant professor Arthur Ramsey has been promoted to a professorship of mathematics at Grove City College.

Miss Ottilia W. Dueker has been appointed professor of mathematics and dean of women at the Friends' University, Wichita, Kansas.

DR. J. S. MiLLER, of Emory and Henry College, has been appointed professor of mathematics at Hampden-Sidney College.

Mr. J. E. DotTerer has been appointed professor of mathematics and physics at Manchester (Indiana) College.

Assistant professor C. P. Sousley, of Pennsylvania State College, has been promoted to an associate professorship of mathematics.

Mr. V. G. Grove, of Cornell University, has been appointed assistant professor of mathematics at the Michigan Agricultural College.

Aт Cornell University, the following appointments to instructorships in mathematics have been made: Dr. H. C. M. Morse, of Harvard University, Mr. P. A. Fraleigh, of Dartmouth College, and Mr. F. M. LuFkin.

Dr. W. H. Wirson, of the Massachusetts Institute of Technology, has been appointed instructor in mathematics at the University of Iowa.

THe following instructors in mathematics have been appointed at the University of Wisconsin: C. D. Ehrman, I. W. Trayler, J. E. Davis, M. Ingraham, F. E. Rechart, Miss E. M. F. Felteges, and Miss B. Albright.

Professor H. G. Zeuthen, of the University of Copenhagen, died January 6,1920 , at the age of eighty years. 
He spent the summer of 1919 in writing a seventy-page paper on the origin of algebra.

REv. C. J. BoRGMEYer, professor of mathematics and astronomy at St. Louis University, died December 6, 1919, at the age of fifty-eight years.

\section{NEW PUBLICATIONS.}

\section{HIGHER MATHEMATICS.}

Barthel (E.). Architektonik der Kegelschnitte. Autographiert. Strassburg, Selbstverlag, 1916.

BAUDET (P. J. H.). Groepentheoretische onderzoekingen. S. Gravenhage, Nijhoff, 1918. 8 vo. $114 \mathrm{pp}$.

BECK (H.). Koordinaten-Geometrie. Berlin, Springer, 1919, 8vo. 432 pp. Geb.

M. 31.00

BlaschKe (W.). Kreis und Kugel. Leipzig, Veit, 1916. $10+169$ pp.

Borel (E.). See Petrovitch (M.).

Bowley (A. L.). General course of pure mathematics from indices to solid analytical geometry. Oxford, University Press, 1919. Cr. 8 vo.

7s. 6d.

Cramer (H.). Sur une classe de séries de Dirichlet. (Diss.) Upsala, 1917.

D'Aruly (G. H.). Sur quelques propriétés des coefficients de certaines séries de Laurent. (Diss.) Upsala, 1917.

Derksen (H. A.). Inleidning tot de hoogere wiskunde, behandelende grafische voorstellingen en de beginselen der differentiaal- en integraalrekening. Zutphen, Thieme, 1919 . 8 vo. $165 \mathrm{pp}$.

Düsivg (K.). Die Elemente der Differential- und Integralrechnung in geometrischer Methode. Mit zahlreichen Beispielen aus der technischen Mechanik von E. Preger. 4te Auflage. Leipzig, M. Janecke, 1917.

Fraenkel (A.). Einleitung in die Mengenlehre. Berlin, Springer, 1919. 8 vo. $156 \mathrm{pp}$.

M. 10.00

HURwirz (A.). Vorlesungen über die Zahlentheorie der Quaternionen. Berlin, Springer, 1919. 8vo. 74 pp.

IsENKRAHE (C.). Das Endliche und das Unendliche. Münster i. W., H. Schöningh, 1915. Gr. 8vo. $8+332$ pp.

Kommerell (K.). See Kommerell (V.).

Kommerell (V.) und Kommerell (K.). Analytische Geometrie. I. 3te Auflage. Tübingen, Laupp, 1917. Geh.

M. 3.60 